\title{
Rule of Law and Codes of Trust. Interdependencies between Legal and Social Institutions: A Case Study of China
}

Michael Baurmann/Liu Mengyue

\section{Introduction}

Formal state institutions like the political and legal order consist of rules that are formally codified and enforced by organizations with coercive power, while informal social institutions refer to the unwritten norms which are enforced outside the officially sanctioned channels. The research on social capital and its impact on the working of a political and legal order focuses on the relations between these two types of institutions. It has one basic message: for a political and legal order to work well and sustainably it is not only dependent on a smartly crafted institutional design with a well-constructed system of incentives, formal controls and coercive mechanisms; at least as important are the supporting social institutions and informal norms which motivate and encourage citizens to cooperate with each other individually and collectively and to contribute voluntarily to the thriving of their political order and its institutions and organs.

This research has provided evidence that well-functioning interpersonal relations and widespread social networks in the private contexts of a vibrant civil society are necessary foundations for the development of essential social virtues such as the capacity to create new relationships ("sociability"), the readiness to participate actively in societal affairs, the commitment to support political and 
legal institutions and to contribute one's share to those public goods which cannot be provided by formal institutions. ${ }^{1}$

"Trust" is a key factor in this context. Only if people trust each other will they be ready to cooperate with their fellow-citizens, to do business with them even when transactions involve risks or work together in a collective enterprise to create common goods in their mutual interest. Only if citizens trust their politicians and civil servants will they support them in their ruling and administrating duties and follow their orders and decisions willingly. And only if politicians and civil servants trust their citizens in turn will they be ready to rule by argument and persuasion rather than by control and sanctions.

The lesson social capital theory teaches us is that the formation and distribution of these different variants of trust are rooted in the informal social institutions and culture of a society and cannot be created artificially by political fiat. But we must be aware of the fact that the "codes of trust" in a society can vary greatly and that it makes a huge difference if people restrict their relationships of trust to a well-defined group with a clear demarcation towards outsiders or if they are also ready to place trust in people who are connected with them only by "weak ties".

We will start with a short recapitulation of the arguments in favour of the relevance of trust and social virtues for the working of a political and legal order and why the social capital of a society is a main factor in the production of such attitudes and virtues. We then explain why it is of central importance to distinguish between different variants of social capital and to be aware of a "black" and a "white list" of social capital. On the basis of a differentiated picture of the relation between formal state institutions and informal social institutions, we will discuss and illustrate the topic with the example of Chinese economic history over the last 40 years - and conclude with some general remarks.

${ }^{1}$ See Banfield (1958); Putnam (1993); Putnam (2000); Putnam (2001); Baurmann (1999); Baurmann (2000); Baurmann (2002); Baurmann (2006); Baurmann (2008); Ostrom/Ahn (2003). 


\section{Economising on Virtue or Taking Virtue Seriously?}

Trustworthiness and virtuousness are valuable and possibly also scarce goods. It is therefore expedient to be sparing with them. This principle of "economising on virtue" ${ }^{2}$ not only applies to the relationship between single individuals but, as the Scottish moral philosophers have taught us, should also be a guideline for the creation of societal and political institutions. The market serves as a paradigmatic example of an arena where the participants' virtues and morals are largely dispensable, and yet where the result of their actions serves everyone's interest and, thereby, the public welfare. Institutions of this kind relieve individuals of the burden of moral duties and reduce the need for social norms as well as for investments to enforce them.

The classical authors of the Scottish Enlightenment were optimistic that this principle could also be transferred to political institutions. Even within the difficult realm of state power, it seemed possible to invent institutions through which an "invisible hand" would aggregate the general pursuit of individual interests to a common good. ${ }^{3}$ This prospect was particularly attractive as one could discard the - possibly futile - Platonic task of controlling the personal ambition of state rulers by instructing them in virtuousness and morality. If, instead, there were ways of shaping the institutional framework of political action so that it would be to the rulers' own advantage to take care of their subjects and the common weal, then trust in politics would become independent of trust in the character of the politicians.

The hope of being able to rely on the "morality" of the political institutions rather than on the morality of the politicians still plays a prominent role in modern political science and social theory and, moreover, in public opinion too. Especially the modern democratic state with its institutionalized possibility of voting politicians out of office, its protection of basic rights, and its ingenious system of the separation of powers and "checks and balances" seems to be the perfect example of a system which by means of cleverly constructed mechanisms prevents state rulers from misusing their power for their own private aims.

\footnotetext{
${ }^{2}$ See Brennan/Hamlin (1995).

${ }^{3}$ See Hirschman (2013).
} 
In recent years, however, the insight has grown among social theorists that the principle of "economising on virtue" has its limits and that we cannot solve all the problems of social and political order by well-designed institutions and their incentives. ${ }^{4}$ The functioning of a well-ordered political and legal system is, to a large extent, not only dependent on the behaviour of politicians or civil servants acting directly under the rules of state institutions, but also on the attitudes and the spontaneous behaviour of the citizens outside formal institutions. Many social scientists today believe that because of this a well-ordered society and its political institutions must be rooted in genuine social virtues and trustworthiness of its members which cannot be traced back to rational opportunistic behaviour under some artificially created extrinsic incentives. ${ }^{5}$

However, there can be no doubt that formal state institutions and the incentives they create matter and that different institutions will produce different outcomes. Institutional rules influence the behaviour of actors inside and outside the institutions. But the effects of institutional design are dependent not only on the properties of the formal institutions themselves. Every state institution is embedded in an environment of informal social institutions and the overall impact of a state institution is not the result of an endogenous equilibrium produced only by the incentives of this institution and the given preferences of the actors. This impact is always a result of an equilibrium which emerges from the characteristics of the formal institution and exogenous forces and conditions. So the same institutional system can have very different outcomes depending on the social context in which it is implemented. The "rules of the game" always include more than deliberately created rules of formal institutions. "Design principles" for formal institutions are clearly relevant for institutional stability and performance - but their exact consequences are not context-independent. ${ }^{6}$

Emphasizing that social virtues are important for making a political order work is therefore not tantamount to assuming that political and legal institutions and their design are irrelevant. To some degree the opposite is true: social virtues do not make formal institutions superfluous, but can serve as a basis for

\footnotetext{
${ }^{4}$ See Baurmann (2000).

5 See Putnam (1993), (2000); Fukuyama (1995a); Pettit (1997); Brennan/Hamlin (2000); Dekker/Uslaner (2001).

${ }^{6}$ See Ostrom (1990), Ostrom (2005).
} 
making these institutions even more successful. We can reach more efficient equilibria by institutional devices if we can rely on the trustworthiness and intrinsic motivation of the actors: it becomes easier to create and change formal institutions, the demand for hierarchy and control in institutions decreases, the tension between formal und social institutional processes diminishes, institutional norms and rules are more readily followed and the commitment to collective decisions under institutional rules increases.

If the outlined thesis is right, the working of a well-ordered society demands a stable equilibrium between proper institutional design and a suitable social environment in which supporting social virtues play a central role. Political and legal institutions can bring about a lot of things - but whether they do so in a desirable way is greatly influenced by factors outside these institutions themselves. The efficiency of state institutions, their stability, their legitimacy and conformity to their norms and rules can only be realized if they are properly implanted in their social soil. It is true that societies can be changed and shaped with the help of state institutions, but how successful this is and what kinds of institutions are necessary cannot be answered in general terms. We cannot simply replace the moral fabric of a society and its spontaneous forces by the incentives of a cleverly designed institutional framework. The working of a society cannot only be based on extrinsically motivated compliance with formal rules but also requires an intrinsically entrenched commitment to fundamental social norms: we have to take virtue seriously!

\section{Bowling Together: Making Democracy Work}

The view that social virtues are essential prerequisites of a good society and a legitimate political order has a long history. The same is true of a family of theories about the factors which promote the desired virtues of citizens. These theories, which go back to Aristotle, were ingeniously renewed in Tocqueville's analysis of democracy in America and in our time have been put in the context of social philosophy by the communitarians. ${ }^{7}$ In the last twenty years, however, a new and promising variant of these theories has been developed by the political scientist Robert Putnam in his pioneering books Making Democracy Work (1993) and Bowling Alone (2000) which initiated a large number

\footnotetext{
${ }^{7}$ See MacIntyre (2007); Etzioni (1993).
} 
of theoretical and empirical studies on the social and cultural fundaments of a well-functioning society.

In a nutshell, these theories share the assumption that social virtues are the product of a particular sort of interpersonal relationship between the members of a society. According to this assumption these civic relationships outside the state domain constitute a special area of a "civil society" whose dynamics are rooted in the aspirations and values of the citizens as private actors. As participants in this kind of private relationship, people will develop capacities and behavioural dispositions which promote their general sociability and cooperativeness and which are therefore beneficial to the society as a whole and will spill over into the public sphere.

To Aristotle this function is fulfilled by friendships which motivate individuals to behave altruistically towards each other and to jointly promote the values of their community. Tocqueville extended Aristotle's view to include all personal relationships which are part of a collective enterprise that people privately and voluntarily initiate to realize a common aim. From his observations he draws the conclusion that by taking part in such associational groups, individuals will overcome short-sighted egoism and will learn to cooperate, to contribute to collective goods, trust each other, and peacefully solve issues of common interest. For Tocqueville the concrete aims, sizes and structures of associational groups are secondary. Whether they are established to build a bridge for a village, to come together to pray or to collect money for a hospital, they will all have beneficial influences on the behaviour and character of their members by turning them into persons who feel responsible for their fellowcitizens and the common welfare.

Whereas the communitarians in some respect go back to Aristotle in emphasizing the importance of common values, uniform convictions and shared traditions as the basis of social virtues, the modern theories in the political and social sciences are more in the spirit of Tocqueville focussing as they do on the variety and diversity of associational activities. They have coined the term "social capital" to summarize the different forms of association which can be produced through the private initiative of the citizens. The exponents of social capital theory believe that there are manifold kinds of social relationships which - although maybe to different degrees - have the capacity to create those special bonds between their participants which promote the development of social virtues: from the weak ties of loose social networks in neighbour- 
hoods, from bowling and bird-watching, soccer-clubs and bible-circles to political parties, NGOs and spontaneous social movements.

According to this view, well entrenched interpersonal relations and widely spread social networks are not only important to provide individuals with access to different kinds of valuable resources. ${ }^{8}$ Being embedded in stable social institutions should also teach the virtues of sociability and the general capacity to create and maintain reciprocal and cooperative relationships, to participate in common tasks and adhere to the principles of fairness. Without being able to overcome the free-rider problem, to act successfully as a collective and feel committed to the rules of a group, most joint enterprises would not get off the ground. Acting in social networks should moreover foster friendly and altruistic personal relationships and thus a general emotional commitment. The norms and rules in networks would honour and sanction personal trustworthiness thereby laying the ground for mutual trust in a society. ${ }^{9}$

The crucial premise of social capital theory is, however, that there is indeed a spill-over, a transfer from the context of the social institutions of privately organized associational life to the society as a whole. But if individuals in a small village learn to behave fairly towards other village members, if they feel an emotional commitment to them and prove themselves to be trustworthy neighbours, will they consequently also be fair, altruistic and trustworthy as citizens of a large society? The exact mechanisms by which membership in associations of civil society leads to a high level of general sociability and widely spread trust are not yet clearly understood. We must gain more insight into which forms and elements of private associations and networks promote the desirable transfer and which do not. Of course, there is undeniable empirical evidence that there are important differences between various forms of social capital in this respect and that not every joint activity is conducive to society and its institutions as a whole.

\footnotetext{
${ }^{8}$ See Coleman (1988); Granovetter (1973), Granovetter (1985).

${ }^{9}$ See Gambetta (1988); Misztal (1996); Fukuyama (1995a).
} 


\section{Making Democracy Worse: the Dark Side of Social Capital}

Timothy McVeigh and his co-conspirators in the Oklahoma City bombing were members of a bowling league: they were not, unfortunately, "bowling alone”. Osama Bin Laden was not acting as an isolated mad man, but was firmly embedded in a well-functioning network of internationally acting terrorists. The so-called Islamic State is not held together by its imitation of state institutions but is based on the unfortunately quite effective social institutions of a deviant community. These extreme examples make clear that successful cooperation to achieve a common aim, or solidarity in a group of like-minded people who may also be emotionally committed and develop stable trust relationships is not automatically desirable for people outside the group or the political order of a society. The collective good for the group could be a public bad for the community. Even when we think of less dramatic possibilities than in the Oklahoma City bombing or in the case of Al Quaida, differential mobilization of the population by ethnic, racial, religious, or other ascriptive criteria can lead to very particularistic demands and will undermine rather than support a society as a whole..$^{10} \mathrm{~A}$ rich network of associational activities and stable social institutions alone are no guarantee of a flourishing society and stable state institutions. They can be both a source of trust and a source of distrust. Instead of promoting sociability and cooperative capacities, they can produce insurmountable conflicts by shaping and organizing antagonistic interests and locking them in an inextricable equilibrium of continuous power struggle and mutual hostility.

Putnam claims as a central result of his studies in Italy that the malfunctions of state institutions in Southern Italy were chiefly a consequence of a low level of social capital. ${ }^{11}$ To generalize this correlation would be misleading. It is not the case that poorly performing societies with defective state institutions always display a low level of social capital. The stability of autocratic and despotic regimes often has two faces: on the one side there may be a fragmented civil society in which more or less isolated individuals live within weak social networks and must endure an underdeveloped associational life - a situation which is often the intentional outcome of a political strategy of the rulers who

\footnotetext{
${ }^{10}$ See Hardin (1995).

${ }^{11}$ See Putnam (1993).
} 
want to prevent the emergence of a strong civil society. But on the other side the members of the ruling oligarchy themselves may be integrated in a social and political network which guarantees a sufficient degree of mutual trust and reciprocity inside the political elite to enable the efficient realization of their collective goods. On this basis the commitment among them can be strong enough to overcome short-term opportunistic and selfish behaviour and achieve beneficial cooperation - which does not exclude the fact that the aim of this cooperation is to suppress and exploit the rest of the society. This also applies to the notorious example of the Mafia: Mafia is a form of social capital as it embodies a highly efficient social network, creates strong norms of honour and reciprocity, and successfully overcomes collective action problems of all. ${ }^{12}$

High levels of social capital can also be a difficult obstacle in the transitional phase from traditional societies to modern democracies. Afghanistan and Albania, for example, are not societies with an especially low level of social capital. In both societies there are at least partially well-functioning social networks, relations of emotional commitment, trust and reciprocity, and the capacity for collective action embodied in traditional structures of families, kinship, clans, and tribes - all of them embedded in a highly respected social and religious tradition which contains values and norms with a considerable degree of legitimacy. The problem here is clearly not a problem of lacking social capital - the problem is the lack of the right kind of social capital. Social capital of a traditional sort may be very efficient in promoting cooperation and trust in certain groups, but at the same time it can be also very efficient in preventing cooperation and trust outside these groups. It is a long-held and quite common opinion that China provides another example of a kind of social capital that bars the way to progress by privileging only closed and traditional communities and thereby preventing the development of a modern market economy. We will come back to this prejudice soon.

We have to acknowledge that social capital can have a dark, even sinister side. $^{13}$ Networks, reciprocity, trust, emotional commitment and altruistic behaviour are good only in the right context. Indeed, some of the communities that have been able to educate their members successfully to behave unselfishly

\footnotetext{
${ }^{12}$ See Gambetta (1993).

${ }^{13}$ See Hardin (1995); Levi (1996); Portes/Landolt (1996); Adler/Kwon (2000).
} 
and to sacrifice their individual interests to the common cause are responsible for the largest catastrophes in the history of mankind.

But also less dramatic excesses prove that well-developed forms of social capital could make a political order and societal life worse instead of making it work. Nepotism, corruption, rent-seeking, or partisanship are all forms of behaviour which are detrimental and destructive to a society. And they are all forms of behaviour which are, as a rule, more successful if carried out in a group as a collective enterprise than as an individual effort (see Baurmann 2005). Not surprisingly we find that empirically all manner of social capital is built around those activities - ranging from loose networks which bring a few people together for a short period of time, to small associations with horizontal relations between members connected by trust and reciprocity, up to large organisations with formal rules and a strict hierarchy. The more developed and the more efficient those forms of social capital are, the worse for outsiders and for society as a whole.

The dark side of social capital is not always connected with obviously condemnable behaviour such as trying to bribe or seek rents at public expense. Negative externalities whereby social capital is used to facilitate collusion among a group can also be generated when particularistic demands are put forward which cannot always be judged as morally wrong at the outset. Mobilization of people to realize their religious visions or to promote the interests of their race or ethnicity can be rooted in moral convictions and personal virtues and can create social capital in a paradigmatic form. Groups and associations like these will often embody dense social networks, high levels of personal trust, altruistically driven reciprocity and generosity, and a strong intrinsic motivation to make sacrifices for the common good.

These forms of social capital will, nevertheless, more often subvert rather than strengthen a society. The reason for this is obvious: associations like these are not "bridging" and "outward-orientated", but centred around people of the same kind or origin and promoting goods which are exclusively valuable to the members of the group. The more successful these associations are, the less their members will have the incentive to cooperate and bargain with other groups on a common basis, but will see the chance to enforce their particularistic interests at the expense of others. Thus social capital in this variant erects barriers of mistrust between people instead of uniting them and contributes to aims and goods which can very easily conflict with the aims and goods of the society 
as a whole. Associational groups of this kind will trigger a vicious circle because they undermine shared interests in a society and thereby create incentives for other groups - who, by themselves, would have no genuine reason to develop in this way - to concentrate exclusively on their members and their particularistic interests as well.

Social networks, emotional commitment and trust alone are therefore not sufficient for a desirable spill-over effect beyond group boundaries. Social capital can also have a dark side as it can embody networks which are not bridges bringing different kinds of people together to promote joint interests, but instruments of separation erecting borders and barriers, and providing an exclusive resource to a special group. Instead of encouraging reciprocal and trustworthy behaviour beyond the confines of a group or association, social capital can contribute to a restriction of reciprocity and trust and lead to an increase in opportunism and distrust outside the respective groups. Social capital can lack positive spill-over effects because it only promotes commitment to the "club" good of a group rather than to the public good of the society as a whole. ${ }^{14}$ Emotional commitment internally to a group can be combined with antipathy towards outsiders and trust could remain particularistic and only encompass the members of one's own group. Clusters of this kind will more likely embody "bonding" than "bridging" social capital and be networks in which the internal strong ties are fostered by the homogeneity of their members. From this "black", negative list results a "white", positive list with those attributes which prima facie can contribute to a spill-over of the social capital of specific groups and communities that is valuable to the society at large. ${ }^{15}$ Thus it is decisive that social networks are not exclusive resources and instruments of separation by which artificial borders are erected against goods and services. The different clusters must instead be embedded in a comprehensive network by which "bridges" are built between the different groups thereby unfolding a potential of inclusion. ${ }^{16}$

We can conclude that the relation between the formal institutions of a political and legal order and the informal social institutions which create the social capital of a society is more complex and differentiated than it may ap-

\footnotetext{
${ }^{14}$ See Stolle (1998).

${ }^{15}$ See Stolle/Rochon (1998); Warren (2001); Paxton (2002).

${ }^{16}$ Baurmann (2006); (2008); Granovetter (1973).
} 
pear at first sight: social institutions can support state institutions in motivating people to behave in ways that are conducive to the stability and flexibility of the formal institutions of a society - this was the main focus of early social capital theory. But social institutions can also erode state institutions in motivating people to behave contrary to the rules and laws that are enacted by political and legal organs. Social institutions can compete with state institutions by creating social relationships and social norms as alternatives to the existing laws and institutions. And social institutions can substitute state institutions if state institutions are defective or too weak to enforce a political or legal order.

We would like to discuss this more complicated picture by means of a concrete and highly interesting example: the example of China and its social, political and economic history over the last 40 years.

\section{Guanxi as the Chinese Social Capital}

After the Cultural Revolution the Chinese people found themselves in a dreadful situation and realized that they could not count on the Communist state for a better life. They then began to revive the resources of traditional social institutions in China which are based on personal networks and emotional bonds. Such relationships are defined as guanxi. The influential Chinese anthropologist, Fei Xiaotong, characterizes guanxi as a "differential mode of association" which he illustrates with the image of "concentric circles formed when a stone is thrown into a lake". ${ }^{17}$ The closer persons are to the actor in the centre, the more easily the actor will trust them and treat them preferentially. But unlike familism or other particularistic relationships which are firmly embedded in kinship, affinity or geographical origin, guanxi is an open and flexible institution. Under market conditions it is a rule that the wider one's social network is, the easier it is to get access to profitable economic transactions.

For this reason the Chinese exploit every chance to extend guanxi in various ways: social occasions such as birthdays, weddings or funerals are taken as opportunities to enhance existing guanxi relations. Mutual friends function as "trust intermediaries" and form bridges to new guanxi partners. Simultaneously the Chinese nowadays are ready to turn away from persons who have earned

${ }^{17}$ Fei (1992), 63. 
a bad reputation even when they are genetically or geographically close. So it is still accurate to state that in the networks of guanxi people are treated particularistically in regard to their position in "the differential mode of association". But these networks can expand dynamically and the position of people in them can change depending on their compliance to the rules of guanxi.

Some scholars consider guanxi as a kind of instrumental relationship which depends mainly on mutual material interests. ${ }^{18}$ But it is an essential feature of guanxi that its instrumental functionality is inseparably linked with its expressive components, especially renqing (personal feeling) and mianzi (face) ${ }^{19}$ It is an efficient strategy in China to utilize the rules of renqing and mianzi as ways and means of influence and manipulation, especially when people with few economic and political resources try to fraternize with people of a higher social rank. This strategy is successful because no matter how economically wealthy or politically powerful certain persons are, they have to be responsive to the requests from their friends and partners in order to maintain renqing and mianzi. The instrumental value of guanxi depends on the fact that Chinese people are willing to invest economic and political resources in the maintenance of guanxi not only for the material profit of long lasting cooperation, but also out of moral commitment and for nurturing a favorable personal reputation. Therefore, instead of being either an instrumental or an expressive social relation guanxi should be understood as a "mixed tie" of instrumentality and expressivity.

It is widely accepted that in China guanxi is the most valuable social capital in everyday life.$^{20}$ However, it is quite controversial which effect guanxi has at a wider societal level. According to Max Weber ${ }^{21}$ the inward feature of Chinese social networks erects borders and barriers between groups rather than bridging them. And this is why a modern market economy could not be born in China. Contemporary social scientists such as Fukuyama hold the same

\footnotetext{
${ }^{18}$ See Sun (1996).

${ }^{19}$ Reqing refers to the expressive feelings between interacting individuals, e.g. empathy. Mianzi refers to personal dignity and reputation. One can lose mianzi by either refusing to do a favour for friends or being refused by friends. More information of renqing and mianzi see Hwang 1987.

${ }^{20}$ See Yang (1994).

${ }^{21}$ Weber (1968).
} 
opinion. He argues that guanxi is responsible for the small scale of business and the widespread corruption in public sectors in China. ${ }^{22}$ From this perspective guanxi actually destroys the foundation of a well-functioning society and its institutions instead of promoting it.

However, the development of China in the last 30 years tells a much more differentiated story. The Chinese economy has been growing at an average of almost $10 \%$ since the beginning of the economic reforms in 1978 - three times the global average. It is hard to believe that a society with a serious shortage of mutual trust and limited skills of cooperation is capable of achieving such an astounding success. For this reason some scholars admit that guanxi actually contributes to the efficiency of economic transactions in China. ${ }^{23}$ Moreover, the extremely adverse political and legal environment at the beginning of the reforms ${ }^{24}$ suggests that the boom of the Chinese private economy in the 1980s is to a great extent to be attributed to social factors - more specifically, to the social institution of guanxi rather than to political and legal institutions of the state.

Therefore, instead of assigning guanxi exclusively and statically to the "black" or "white" list of social capital, we will analyze its development as an adaptation to a dynamic social and institutional framework. Guanxi is not a static institution and its role as social capital has undergone significant changes during the last decades of Chinese history. Especially its relation to the political and legal institutions has altered significantly and developed from an institution that promoted the establishment of an efficient market economy in confrontation with the political system to an institution that strengthens corrupt relations between entrepreneurs and state officials and weakens economic productivity. This historical clue will help us to gain a better understanding of guanxi as social capital and its complex interdependencies with the political and legal institutions in China.

\footnotetext{
${ }^{22}$ Fukuyama (1995a), Fukuyama (1995b).

${ }^{23}$ See Wong/Chan (1999); Wong/Leung (2001); Yeung/Tung (1996).

${ }^{24}$ In the 1980s there was not only no formal protection of private property rights, but the Communist Party of China (CCP) also imposed extensive restrictions on the private sector. Any economic activity crossing these lines would be punished in the name of "speculation". We will discuss this later in this paper.
} 


\section{Evolving the Chinese Market Economy}

According to theories in the tradition of institutional economics well-defined property rights are the prerequisite of a flourishing market economy. In a society without an effective legal order and enforceable rules everybody is involved in "the war of all against all" and thus any form of efficient economic exchange is hampered. The exit option from such a "Hobbesian jungle" is to establish powerful state institutions that can guarantee a stable order of cooperation. Seen from this perspective, the economic performance of a society depends vitally on the efficacy of coercive instruments of the state in protecting private property and punishing those who disobey the laws. Douglass North consequently assumes that the rise of the Western World would not have been possible without its efficient institutional protection of private property. ${ }^{25}$

However, the growth of the Chinese private economy is quite different from its western counterparts. At the beginning of the economic reform in the 1970s the CPC (Communist Party of China) decided to shift its focus from political campaign to centrally administered economic development. Stateowned enterprises were the main concern and as at that time the Party had no intention of encouraging private enterprises or a market economy in general. Consequently, during the 1970s and 1980s no laws were enacted in order to protect market contracts or private property. If Chinese citizens wanted to conduct private transactions at that time, they had to act in a "Hobbesian jungle" where opportunist behaviour or the breach of contracts was not prevented or punished by formal institutions.

But not only "predation" in the "Hobbesian jungle" threatened the first generation of Chinese entrepreneurs. There was also discrimination and persecution by state organs - the "Leviathan". Heavy tax was imposed on private enterprises and time-consuming bureaucratic procedures had to be followed. Private entrepreneurs were not allowed to employ more than seven employees before 1987 and, in addition, their economic activities were discreetly controlled by the authority. Any private transactions not complying with these prescriptions would be punished as "crimes of speculation", a kind of crime that was codified in 1979 and eliminated only in 1997. According to the study

${ }^{25}$ North/Thomas (1973). 
by Xiaobo $\mathrm{Wu}^{26}$ around 30,000 people were convicted of the crime of speculation in 1982, most of whom were successful private entrepreneurs. Obviously, the original purpose of the Party was to protect the state-owned and collective economy from competition in the market. The fact that the private economy finally grew "out of the plan" (see Naughton 1995) was unexpected and unwanted.

Therefore, rebutting conventional wisdom, the legal institutionalization of private property followed the growth of the private economy in China, not the other way round. ${ }^{27}$ In order to understand the Chinese economic "miracle", it is necessary to focus on the social institutions that made private economic activity and the development of markets possible without legal authorization and a formal protection of property rights.

The greatest challenge to the first generation of Chinese entrepreneurs was to protect private property from the threat of "Leviathan", namely from the Communist state and its jurisdiction. Hundreds of thousands of entrepreneurs were doing business "illegally" at risk of imprisonment. In view of this difficult situation, Chinese entrepreneurs came up with organizational innovations to feign collective ownership which could save them from prosecution by the state. The two most important innovations were shareholding corporatives and "red hat" enterprises. In a shareholding corporative several families joined together to run a business. All the family members were owners as well as the employees of the corporative. A "red hat" enterprise was a private enterprise that was registered as a collective one. Nominally these enterprises belonged to the local governments but were actually under the control and part of the "informal" property of individuals. In both cases the enterprises founded by private citizens were disguised as being in collective ownership.

That does not mean that faked collective ownership was without dangers and risks. As a new form of economic organization, a shareholding corporative was not clearly defined as a collective enterprise by the central authority until 1990. Thus its survival and development relied mainly on the local policies of the cadres on-site. In the same way "red hat" enterprises were neither clearly encouraged nor forbidden by the CPC, leaving the local governments plenty of room for dealing with this novel form of economic business at their own dis-

\footnotetext{
${ }^{26} \mathrm{Wu}$ (2007), 85.

${ }^{27} \mathrm{See} \mathrm{Li/Li/Zhang} \mathrm{(2000);} \mathrm{Lin} \mathrm{(1989);} \mathrm{Naughton} \mathrm{(1995);} \mathrm{Nee/Opper} \mathrm{(2012).}$
} 
cretion. As Donald Clarke remarks, local party officials and bureaucrats could easily regain the actual control over these enterprises by changing their policies. The private owners of the enterprises would be demoted "to mere employees with no right to a return on the capital that they had invested". ${ }^{28}$ However, local cadres normally did not exploit the situation for their private gains but instead protected and encouraged these institutional inventions in many areas from below. Because of this support from local governments, shareholding corporative and "red hat" enterprises became very successful and popular all over the country in the 1980s. More remarkably, they contributed a great part to the national economic growth although the policies of the central government in that period were extremely unstable and unpredictable. ${ }^{29}$

Why were the local cadres in fact willing to help private entrepreneurs despite their extremely dominant position in relation to these entrepreneurs? The crucial factor was their joint embeddedness in the social institution of guanxi and their subjection to the same social forces created by this institution. Unlike economic or political power, the social power of guanxi is generated by personal interactions in everyday life. It is a binding social obligation for Chinese to maintain affective and reliable relationships with their relatives, friends and partners via regular gift-giving and invitations to banquets. Through these frequent exchanges and their contribution to stable interpersonal ties and reciprocal commitments an effective social power is created which can trump political and economic power. Especially in smaller towns and villages this power can be particularly strong because people are closely connected through kin, marriage and long-lasting personal acquaintance.

Therefore, in the aftermath of the Cultural Revolution rural cadres found it more and more difficult to maintain and make use of their formal power. They were integrated in the social institutions of their communities and social pressure caused them to accept bargains and compromises with villagers who were their relatives and friends. When state policies came into direct conflict with the interests of the communities, the cadres usually chose to protect the interests of local people by deceiving the state officials. Observing this phenomenon Yun-xiang Yan concludes: "the new pattern of political behavior among the rural cadres might create an informal mechanism to counterbalance and resist

\footnotetext{
${ }^{28}$ Clarke (1991), 305.

${ }^{29}$ See Nee/Opper (2012); Tsai (2007); Whiting (2006).
} 
state control of society and the negative effects of central policy". ${ }^{30}$ Similarly, Yusheng Peng (2004) found a solid and positive correlation between the solidarity of kinship and the prosperity of private economy in Chinese villages: the more closely villagers are socially connected to each other, the more likely local cadres submit to the social norms of guanxi and the better the local economy develops. The fact that local cadres in rural areas are particularly committed to their fellow-citizens due to the strength of social networks in these areas can partly explain why in the early 1980s private entrepreneurship was developing most vibrantly in the poorest and most rural regions of China. ${ }^{31}$

In dealing with local cadres Chinese entrepreneurs successfully utilized the norms and rules of guanxi. For example, instead of offering direct bribes, private entrepreneurs tried to produce or intensify emotional bonds between the cadres and themselves via gift-giving and invitations to banquets, which gave rise to obligations and indebtedness. The skills and techniques of creating genuine guanxi relationships are known in China as guanxixue (guanxi studies) which refers to the capability of establishing and manipulating guanxi for one's own purposes. With this capability private entrepreneurs could influence relevant cadres even when they had no relationship of blood and affinity. As Mayfair Yang observes:

"Gift-giving creates a microcosmic world in which hierarchical relations are to a certain extent reversed. Donors become the moral superiors of recipients, who now owe favors to their donor. Symbolic capital compensates for the lack of material, office, or political capital. Thus face and the morality of reciprocity, obligation, and indebtedness become in a sense the ammunition of the weak. This mobilization of the forces of gift morality effects a subtle displacement of the potency by diversifying the state economy's principle of classification and distribution by rank. "32

From this point of view guanxi was the most powerful "weapon of the weak" (Scott 1985). Through a sophisticated use of this weapon officially discriminated private entrepreneurs successfully created a "microcosmos" in which they could counter the political power of the central authority as well as avoid the possible economic extortion by the local governments. Guanxi helped them to

\footnotetext{
${ }^{30}$ Yan (1995), 230.

${ }^{31}$ In regard to the robust development of the private economy in the rural areas of China see Huang 2008.

${ }^{32}$ Yang (1994), 206.
} 
create a small safe environment in an unfriendly political and legal institutional framework and to achieve a thriving private economy in China.

In a similar way the "microcosmos" of guanxi also helped the first generation of Chinese entrepreneurs to deal with the second challenge they faced in the early years of the private economy in China, namley to secure their economic transactions against fraud and deception by private parties without any legal protection. As already emphasized, if the Chinese wanted to conduct private transactions at this time, they had to act in a world where opportunist behaviour or the breach of contracts would hardly be punished by the formal institutions of a legal order. But the norms and rules of guanxi were not only strong social forces that integrated state officials in an efficient network of mutual trust and commitment, they also created social capital that provided a dense web of stable social relations in which economic exchange could successfully take place without the protective shield of institutionalized property rights and a reliable contract law. Stable interpersonal relations and reciprocal commitments which are created by guanxi produce binding obligations and affective ties between entrepreneurs and state officials but also between the private actors on the market in their economic transactions.

\section{Establishing the Chinese Market Economy}

In the 1980s the Chinese private entrepreneurs had achieved tremendous success and changed the whole economic landscape of China. Realizing reluctantly that the bottom-up privatization had greatly stimulated the national economy despite its inconsistency with the Communist ideology, the central authority began to legalize the private firms and to gradually establish a market economy from the end of the 1980s. For example, in 1987 the restriction of a maximum of seven employees in private firms was removed and in 1997 the crime of "speculation" was eliminated from criminal law. The property rights of private entrepreneurs were officially admitted and protected by the state authority, thus rendering fake collective ownerships superfluous. ${ }^{33}$ Some scholars believed that guanxi would lose its importance once the formal protection of private property became available (Guthrie 1998). This prediction failed. De-

\footnotetext{
${ }^{33}$ See Kung (1999).
} 
spite the dramatic changes in the formal institutional environment in China, guanxi still plays an important role in everyday life and economic contexts. ${ }^{34}$ Still today foreign investors are advised to learn the rules of guanxi - namely the rules of mianzi and renqing - if they want to build trust relationships with their Chinese partners (Buckley/Clegg/Tan 2006).

The persistence of guanxi results from two facts. Firstly, although the protection of private property rights was finally added in a constitutional amendment in 2004, the enforcement of formal laws in China is still weak, costly and unreliable. To press a charge against a person for a criminal or civil offence and realize a conviction is time-consuming and incalculable, especially when government officials are involved. ${ }^{35}$ It is more efficient and less risky to resolve conflicts or problems via personal networks rather than through formal procedures.

The second reason is that even in a developed market economy guanxi can still contribute significantly to a well-functioning and sustainable order of economic cooperation. It has often been argued that guanxi as a social institution is incompatible with a modern market because guanxi mechanisms are restricted to local networks that divide markets into small segments. These restrictions would prevent the advantages of an efficient division of labour and large companies with economies of scale would not be feasible. ${ }^{36}$ However, as Yang suggests, guanxi should be recognized as "a multifaceted ever-changing set of practices". ${ }^{37}$ On the one hand, market relationships are structured by guanxi, yet on the other hand, the dynamics of markets force guanxi to evolve. After the successful establishment of a market economy the main challenge of Chinese entrepreneurs is not the intensity of guanxi but its extensity. the larger and wider social networks of persons become, the more chances they will have at the marketplace to establish profitable and stable economic relationships. Under these conditions ties of kinship and affinity alone could no longer satisfy private entrepreneurs who wanted to expand their business and to seize the opportunities a growing market offers.

\footnotetext{
${ }^{34} \mathrm{Su} /$ Littlefield (2001); Yang (2002).

${ }^{35}$ Nee/Opper (2012), 7-8.

${ }^{36}$ Fukuyama (1995b); Weber (1968).

${ }^{37}$ Yang (2002), 459.
} 
The most practical way to enlarge one's networks is to use the social capital of an existing guanxi. For example, one can establish guanxi with a stranger via a mutual friend. A person will trust a stranger if a mutual friend forms a bridge and a bond between them: all persons in this new triangle have to respect the mianzi of each other because humiliating the new acquaintance - e.g. by refusing a request - will also hurt the old friend and if one owes a renqingfavor of his or her friend, he or she will usually feel responsible for the newly introduced stranger. In this way trust and commitment can be transferred by intermediaries from one relationship to another. Mianzi and renqing function as universal media which can flow from hand to hand thereby creating widespread and inclusive social and economic networks.

Therefore, even in a modern market economy guanxi as a social institution is effective in promoting the social virtues of cooperation and trustworthiness and thereby reducing the costs and risks of economic exchanges and promoting the overall functionality of a market. Some scholars thus assume that guanximediated market processes are to be seen as a genuine alternative to the western market system. Moreover, with regard to low transaction costs and strong commitment guanxi may be even more efficient than the western style market mechanisms. $^{38}$

Given the ongoing weakness of legal institutions and the high degree of adaptability of guanxi to the demands of modern markets it makes sense for Chinese entrepreneurs to stick to the traditional social institutions when looking for security and protection of their interests. The more entrepreneurs try to solve problems via personal ties, the more refined their skills of guanxi become. And the greater the resources of guanxi which are accumulated, the more reluctant they will be to resort to formal procedures. In this way the social institution guanxi has managed successfully to substitute suboptimal and defective formal institutions and fulfil functions that from a standard point of view are the exclusive responsibility of state organs.

${ }^{38}$ See Lovett/Simmons/Kali (1999). 


\section{Undermining the Chinese Market Economy}

However, guanxi has also revealed dark sides as social capital. In supporting economic transactions it strengthens social virtues of cooperation, facilitates mutual trust between exchange partners and increases the level of sociability. But when political agents are involved, guanxi tends to establish patron-client relationships which jeopardize economic efficiency by distorting market mechanisms and favouring preferential intervention. Actually, pursuing political patronage via guanxi is not a new phenomenon concomitant with the market economy in China. This strategy was already widely utilized in socialist factories in Mao's era when the workers tried to build affective personal ties with their leaders for the sake of political, material and career advantages. ${ }^{39}$ In the 1980s, as already described above, Chinese peasant entrepreneurs successfully forced local cadres to provide a "political shelter" against the state with the help of personal connections in clan and kinship. ${ }^{40}$ But while in Mao's era patron-client relationships actually supported the CPC in incorporating the society into the communist system, ${ }^{41}$ and in the 1980 s stimulated the economic growth of the whole country by establishing competing social institutions that promoted the emergence of markets, patron-client relationships based on the guanxi culture have now become negative factors that hinder the further political and economic development of China.

As the institutional environment changed, political favours that were formerly used for securing private property or protection against state control came to signify new messages for the market participants: the opportunity for additional personal advantages that could be gained through corruption in politicized markets. For example, on the stock and real estate markets which are strictly constrained by the government, market participants are tempted to establish reliable guanxi with relevant cadres in order to gain more profit through their special protection. With the help of cadres one can acquire a personal fortune by buying personal stocks with public funds or renting land at extremely low costs. ${ }^{42}$ The seductive prospects of realizing huge profits by

\footnotetext{
${ }^{39}$ See Walder (1986).

${ }^{40}$ See Peng (2004).

${ }^{41}$ Walder (1986), 123.

${ }^{42}$ Gong (1997), 279.
} 
the circumvention of market mechanisms motivate many Chinese entrepreneurs to invest in the competition for political power instead of in the competition for customers thereby destroying the most important foundation of the "wealth of nations".

Obviously, in this "power game" ${ }^{43}$ only a small fraction of the participants can win, while most of them will lose. But, as Chenting Su and James Littlefield observe, "even though power is quite scarce in today's China, the populace is still actively having a hand in carving up monopolized interests by means of their specific qinyou ${ }^{44}$ guanxi web". ${ }^{45}$ Why are the Chinese still clinging to such ineffective competition even though the overall return from this form of guanxi is dramatically decreasing? The reason is the social embeddedness of corruption. Even though the purposes and consequences of patronclient relationships in China have changed, renqing and mianzi are still the most important norms of these relations. Thus, political power in China is not arbitrarily abused but distributed according to the rules of guanxi. This means that the relation between entrepreneurs and cadres is not simply an exchange of money and favors. One famous example is Lai Changxin, the central figure in an enormous corruption scandal that exploded in the Chinese city of Xiamen in 1998. Having started from a lower social class Lai successfully built guanxi connections with dozens of local cadres. With their help he quickly became the most powerful and wealthy man in Xiamen by smuggling luxury cars and entire tanker-loads of oil into China. Mark Granovetter, inspired by the story of Lai, comments:

"Elaborate systems of gift giving, banquets, entertainment, and favors keyed to the highly particular needs of officials are developed. Whereas a cash payment to the official would be considered an insult, the banquets and special favors can be thought of as a form of deference, which the higher-status person can imagine is owed to him. "46

The social embeddedness of corruption has two effects. Firstly, the role of guanxi in patron-client relationships provides chances even for those people who come from lower classes. As the story of Lai tells, access to higher-ranking cadres is not exclusive to social elites. Anyone who acquires sufficient skills of

\footnotetext{
${ }^{43}$ See Hwang (1987).

${ }^{44}$ Qinyou is a Chinese word meaning relatives and friends.

${ }^{45} \mathrm{Su} /$ Littlefield (2001), 205.

${ }^{46}$ Granovetter (2007), 158.
} 
guanxi has the chance to improve his or her social status. Because of the wide range of social networks, most Chinese can establish guanxi even with high profile cadres via intermediaries. Secondly, guanxi restrains cadres from abusing their political power ad libitum. Cadres do not only value financial returns but also their personal reputation in the relevant social networks. They like to think that they are not actually bribed but simply receive gifts from friends and returned favours. Because of these social and moral constraints, the behaviour of cadres in China is predictable and maneuverable which is different from the corruption in Africa where officials exploit their power arbitrarily and without scruples. ${ }^{47}$

Therefore, even though most Chinese acknowledge the notorious deficiency of their political and legal institutions, they are quite confident that they have sufficient skills and capacities to utilize their guanxi resources and take advantage of the deficient political system to secure their personal interests (see Sun 1996, 30). In this way guanxi not only undermines the mechanisms of a market economy but also discourages people from demanding further institutional development. This is one reason why, contradictory to the prognoses of many scholars, ${ }^{48}$ China has failed to evolve into a democratic society after its astounding economic achievements and instead become a "capitalism without democracy" (Tsai 2007).

\section{Interdependencies between Legal and Social Institutions}

The experience of China supports social capital theory in its central claim that political and legal institutions are not the only forces that affect the trajectory of societal development but that social institutions like guanxi have a strong impact on the dynamics of a society and the performance of the formal state institutions. However, the Chinese case also makes clear that the relation between the formal institutions of the state and the informal institutions of social capital are complex and diverse. As we have seen, social norms that are enforced by guanxi relationships in everyday life can neutralize the economic and political advantages of the ruling powers and provide ordinary citizens with

\footnotetext{
${ }^{47}$ See Heberer (2005), 334.

${ }^{48} \mathrm{Hu}$ (2000); Lollar (1997).
} 
opportunities to initiate a progressive development of the economic system. However, the same social institution can in other contexts discourage the potential challengers of a political order and undermine economic efficiency and progress.

To achieve a more differentiated picture of the possible relations between formal state institutions and informal social institutions it is helpful to adapt a fourfold table proposed by Gretchen Helmke and Steven Levitsky. ${ }^{49}$ They suggest using two dimensions: whether a social institution is convergent or divergent in relation to state institutions which are, in turn, divided into effective and ineffective institutions with respect to their more or less successful enforcement:

Table 4: Interdependencies between Legal and Social Institutions

\begin{tabular}{|l|c|c|}
\hline & $\begin{array}{l}\text { Effective state institu- } \\
\text { tions }\end{array}$ & $\begin{array}{l}\text { Ineffective state insti- } \\
\text { tutions }\end{array}$ \\
\hline $\begin{array}{l}\text { Convergent social in- } \\
\text { stitutions }\end{array}$ & Supporting & Substituting \\
\hline $\begin{array}{l}\text { Divergent social insti- } \\
\text { tutions }\end{array}$ & Eroding & Competing \\
\hline
\end{tabular}

Source: Helmke/Levitsky (2004), 728 (slightly changed)

This typology can enhance our analysis of institutional development. We can recapitulate the institutional evolution in China with its ongoing changes between formal and informal institutions by using this table with the different outcomes it signifies.

In Mao's era (1949-1976) the most important formal institution in China was the Communist political system whose rules and norms were strictly enforced. Many Chinese people were convinced that the CPC would establish a wealthy communist society. Social institutions like universalistic comradeship were promoted and widely accepted for the purpose of the realization of a Communist society. In the spirit of comradeship study groups were established for studying and spreading Marxist-Leninist theory and the thoughts of Mao Zedong, and "revolution groups" were established for promoting the class campaigns. These social institutions were convergent with effective state insti-

${ }^{49}$ Helmke/Levitsky (2004). 
tutions and supported the CPC in reshaping China into a Communist state. They later developed into the radical political movement of the Cultural Revolution.

After the disastrous economic failure of the Communist system the Chinese became tired of political movements and sceptical about the economic prospects of a centrally planned command economy. Chinese people started to revitalize traditional social institutions and developed the social capital of guanxi independent of the state. As mentioned above, on the basis of this social capital private entrepreneurs invented "shareholding cooperatives" and "red hat enterprises" in the 1980s in order to broaden their business and avoid being accused of the "crime of speculation". These practices did not openly contradict the laws and on the surface were compatible with the legal order. But they violated the "spirit" of the laws and the original intention of the CPC which at the beginning of the reform tried to restrict the development of a private economy. Eventually the people managed to establish informal property rights on the basis of a working social institution that successfully confronted the state institutions. With the help of guanxi, divergent social institutions were established that started to undermine and erode the state control of the economy.

After the market economy was finally introduced as the fundament of the national economy, laws were enacted for the protection of private property and the enforcement of contracts. However, guanxi was not completely replaced by formal rules and institutions because of their weak and uncertain enforcement. Chinese entrepreneurs therefore still use guanxi to ensure economic transactions and create stable business relations. Guanxi is a convergent social institution in this case because it is compatible with formal rules and procedures but also a substitute for state institutions which are not effective enough to create a sufficiently stable environment for economic actions.

What we see now, however, is the transformation of guanxi into a new form of divergent and competing social institution. In the 1980s guanxi relations with political cadres were used to gradually establish a market economy and thereby promote economic efficiency. Today guanxi networks in the political realm are used more and more as instruments for rent-seeking and receiving privileges, to circumvent market competition or evade legal prescriptions. This development endangers economic productivity and undermines the efficiency 
of market mechanisms - just the contrary effect guanxi had in the era of the development of a market economy in China.

Many social scientists acknowledge that a gradual process of reform is the secret of China's success. ${ }^{50}$ At the beginning Chinese entrepreneurs tried to circumvent formal rules that restricted private economic activity. They revitalized and renewed the social institutions of guanxi for this purpose. These social institutions successfully eroded the Communist economic order and managed to compete directly with the political and legal institutions as the state's power waned. Finally, the relevant laws were changed in acknowledgment of the factual developments. In this way the radical institutional changes in China were realized piece by piece through the institutional inventions from below and the official recognition from above. Thus, bottom-up initiative, experimentation, learning, and adaptation form the core of the institutional changes in China.

However, this is not the whole story and not the only lesson Chinese history taught us about the relationship between formal state institutions and informal social institutions. The chain of causes must be analysed not only from social capital to legal and political institutions but also vice versa. If our analysis is correct and the dark side of guanxi as social capital is gaining momentum in China as an effective instrument of socially embedded corruption then this development must be combatted by enforcing an efficient rule of law.

As we said at the outset, the overall state of a society is always an equilibrium between the forces of formal and informal institutions. But if a society is in the grip of the dark sides of social institutions, a new and improved equilibrium cannot be initiated without the intervention of the legal and political institutions of the state - which is especially challenging if these institutions are not supported by convergent social institutions: that is the message from social capital theory that remains valid.

Insofar it is not surprising that China has failed to stimulate a new round of effective political and legal reforms up to now. Public authorities are often compromised via guanxi and most Chinese still believe that they can take advantage of the status quo using their guanxi skills and resources. Further institutional reforms will not happen before most Chinese realize that only a small amount of players can win in the "power game" but that all could benefit from

${ }^{50}$ Jefferson/Rawski (1994); Naughton (1995); Rawski (1999). 
a firm rule of law. At this point one must hope that social capital will enter the stage once again in its heroic role and that Chinese citizens will create a social force to influence state policies to the better. Because of the strict control of the government, there are few civil organizations similar to such associations in Western democracies, but citizens in China are as always connected via personal ties and social networks in their guanxi relations. Maybe guanxi will again demonstrate its flexibility and adaptability and acquire a new meaning in shaping the social fabric of an independent civic realm in which the interests and preferences of citizens are formed and articulated. In this way a civil society of its own kind may be realized in China, different in its foundation and profile from Western society but perhaps as powerful and beneficial as it was during the realization of a market economy in the face of counteracting political forces.

\section{Conclusion}

We started our paper with a theoretical discussion of social capital. In order to gain a more complex and appropriate understanding of social capital and its dimensions and impacts, we referred to the Chinese experience of the last 40 years. The tremendous success China has achieved as well as the huge challenges it now faces could in great part be attributed to Chinese-style social capital: guanxi, which exerts both a positive and negative influence on the transition of Chinese society. We learn from this study that first, social capital cannot be viewed simply as an exclusively benign social resource, second, that the societal impact of social capital not only depends on its own features but also on its economic and political context, and, finally, that a promising and underexposed field of research lies in the dynamic interaction between formal institutions such as the rule of law and social capital as a social institution: how they conflict, coexist and adapt to each other. Insight into this process may improve our understanding of institutional change and the determining factors of its notorious path dependency. 


\section{References}

Adler, Paul S./Kwon, Seok-Woo (2000): Social Capital: The Good, the Bad, and the Ugly. In: Lesser, Eric E. L. (ed.): Knowledge and Social Capital. Boston. 89-115.

Banfield, Edward C. (1958): The Moral Basis of a Backward Society. New York.

Baurmann, Michael (1999): Solidarity as a Social Norm and as a Constitutional Norm. In: Bayertz, Kurt (ed.): Solidarity. Dordrecht. 243-272.

Baurmann, Michael (2000): Legal Authority as a Social Fact. In: Law \& Philosophy (19), 247-262.

Baurmann, Michael (2002): Vertrauen und Anerkennung. In: Maurer, Andrea/Schmid, Michael (eds.): Neuer Institutionalismus. Frankfurt. 107-133.

Baurmann, Michael (2005): Korruption, Recht und Moral. In: von Alemann, Ulrich (ed.): Dimensionen politischer Korruption. In: Politische Vierteljahresschrift, Sonderheft 35, 164-182.

Baurmann, Michael (2006): Markt und Soziales Kapital. In: Ballestrem, Karl K. G./Gerhardt, Volker (eds.): Politisches Denken Jahrbuch. Berlin. 129155.

Baurmann, Michael (2008): Political Norms, Markets and Social Capital. In: Kühnelt, Jörg (ed.): Political Legitimization without Morality? Dordrecht. 161-180.

Brennan, Geoffrey/Hamlin, Alan (1995): Economizing on Virtue. In: Constitutional Political Economy 6(1), 35-56.

Brennan, Geoffrey/Hamlin, Alan (2000): Democratic Devices and Desires. Cambridge.

Buckley, Peter J./Clegg, Jeremy/Tan, Hui (2006): Cultural Awareness in Knowledge Transfer to China: The Role of Guanxi and Mianzi. In: Journal of World Business 41(3), 275-288.

Clarke, Donald C. (1991): Regulation and Its Discontents. Understanding Economic Law in China. In: Stanford Journal of International Law 28, 283322.

Coleman, James (1988): Social Capital in the Creation of Human Capital. In: American Journal of Sociology 94, 95-120.

Dekker, Paul/Uslaner, Eric M. (eds.) (2001): Social Capital and Participation in Everyday Life. New York. 
Etzioni, Amitai (1993): The Spirit of Community: Rights, Responsibilities, and the Communitarian Agenda. New York.

Fei, Xiaotong (1992): From the Soil: The Foundations of Chinese Society. Berkeley.

Fukuyama, Francis (1995a): Trust: Social Virtues and the Creation of Prosperity. New York.

Fukuyama, Francis (1995b): Social Capital and the Global Economy. In: Foreign Affairs, 89-103.

Gambetta, Diego (ed.) (1988): Trust: Making and Breaking Cooperative Relations. New York.

Gambetta, Diego (1993): The Sicilian Mafia: The Business of Private Protection. Cambridge.

Gong, Ting (1997): Forms and Characteristics of China's Corruption in the 1990s. Change with Continuity. In: Communist and Post-Communist Studies 30(3), 277-288.

Granovetter, Mark (1973): The Strength of Weak Ties. In: American Journal of Sociology 78(6), 1360-1380.

Granovetter, Mark (1985): Economic Action and Social Structure: The Problem of Embeddedness. In: American Journal of Sociology 91(3), 481-510.

Granovetter, Mark (2007): The Social Construction of Corruption. In: Nee, Victor/Swedberg, Richard (eds.): On Capitalism. Redwood City. 152-172.

Guthrie, Douglas (1998): The Declining Significance of Guanxi in China's Economic Transition. In: China Quarterly 154, 254-282.

Hardin, Russell (1995): One for All: The Logic of Group Conflict. Princeton.

Hirschman, Albert O. (2013): The Passions and the Interests. Political Arguments for Capitalism Before its Triumph. Princeton.

Heberer, Thomas (2005): Korruption in China. Dimensionen politischer Korruption, Beiträge zum Stand der internationalen Forschung. In: von Alemann, Ulrich (ed.): Dimensionen politischer Korruption. In: Politische Vierteljahresschrift, Sonderheft 35, 328-349.

Helmke, Gretchen/Levitsky, Steven (2004): Informal Institutions and Comparative Politics: A Research Agenda. In: Perspectives on Politics 2(4), 725-740.

$\mathrm{Hu}$, Shaohua (2000): Explaining Chinese Democratization. Westport.

Huang, Yasheng (2008): Capitalism with Chinese Characteristics. Entrepreneurship and The State. Cambridge. 
Hwang, Kwang-kuo (1987): Face and Favor: The Chinese Power Game. In: American Journal of Sociology 92(4), 944-974.

Jefferson, Gary H./Rawski, Thomas G. (1994): Enterprise Reform in Chinese Industry. In: The Journal of Economic Perspectives 8(2), 47-70.

Kung, James Kai-Sing (1999): The Evolution of Property Rights in Village Enterprise. In: Oi, Jean J. C./Walder, Andrew A. G. (eds.): Property Rights and Economic Reform in China. Redwood City. 95-122.

Levi, Margaret (1996): Social and Unsocial Capital: A Review Essay of Robert Putnam's Making Democracy Work. In: Politics \& Society 24(1), 45-55.

Li, Shaomin/Li, Shuhe/Zhang, Weiying (2000): The Road to Capitalism. Competition and Institutional Change in China. In: Journal of Comparative Economics 28(2), 269-292.

Lin, Cyril Zhiren (1989): Open-ended Economic Reform in China. In: Nee, Victor/Stark, David/Selden, Mark Stark (eds.): Remaking the Economic Institutions of Socialism. Redwood City. 95-136.

Lollar, Xia Li (1997): China's Transition Toward a Market Economy, Civil Society, and Democracy. Bristol.

Lovett, Steve/Simmons, Lee C./Kali, Raja (1999): Guanxi Versus the Market: Ethics and Efficiency. In: Journal of International Business Studies 30(2), 231-247.

MacIntyre, Alasdair (2007): After Virtue. Indiana.

Misztal, Barbara A. (1996): Trust in Modern Societies: The Search for the Bases of Social Order. Cambridge.

Naughton, Barry (1995): Growing Out of the Plan: Chinese Economic Reform, 1978-1993. New York.

Nee, Victor/Opper, Sonja (2012): Capitalism From Below. Cambridge.

North, Douglass Cecil/Thomas, Robert Paul (1973): The Rise of the Western World. A New Economic History. Cambridge.

Ostrom, Elinor (1990): Governing the Commons: The Evolution of Institutions for Collective Action. Cambridge.

Ostrom, Elinor (2005): Understanding Institutional Diversity. Princeton.

Ostrom, Elinor/Ahn, T. K. (eds.) (2003): Foundations of Social Capital. Cheltenham.

Paxton, Pamela (2002): Social Capital and Democracy: An Interdependent Relationship. In: American Sociological Review 67, 254-277. 
Peng, Yusheng (2004): Kinship Networks and Entrepreneurs in China's Transitional Economy. In: American Journal of Sociology 109(5), 1045-1074.

Pettit, Philip (1997): Republicanism: A Theory of Freedom and Government. Oxford.

Portes, A./Landolt, P. (1996): The Downside of Social Capital. In: The American Prospect 26, 18-22.

Putnam, Robert D. (1993): Making Democracy Work: Civic Traditions in Modern Italy. Princeton.

Putnam, Robert D. (2000): Bowling Alone. The Collapse and Revival of American Community. New York.

Rawski, Thomas G. (1999): Reforming China's Economy: What Have We Learned. In: The China Journal (41), 139-156.

Scott, James C. (1985): Weapons of the Weak: Everyday Forms of Peasant Resistance. New Haven.

Stolle, Dietlind (1998): Bowling Together, Bowling Alone: The Development of Generalized Trust in Voluntary Associations. In: Political Psychology 19(3), 497-525.

Stolle, Dietlind/Rochon, Thomas R. (1998): Are All Associations Alike? Member Diversity, Associational Type, and the Creation of Social Capital. In: American Behavioral Scientist 42(1), 47-65.

Su, Chenting/Littlefield, James E. (2001): Entering Guanxi: A Business Ethical Dilemma in Mainland China? In: Journal of Business Ethics 33(3), 199210.

Sun, Liping (1996): “Guanxi”, Social Relationship and Social Structure. In: Sociological Studies 5, 20-30.

Tsai, Kellee S. (2007): Capitalism without Democracy: The Private Sector in Contemporary China. New York.

Walder, Andrew G. (1986): Communist Neo-traditionalism: Work and Authority in Chinese Industry. Berkeley.

Warren, Mark R. (2001): Dry Bones Rattling: Community Building to Revitalize American Democracy. Princeton.

Weber, Max (1968): The Religion of China. Confucianism and Taoism. New York.

Whiting, Susan H. (2006): Power and Wealth in Rural China. The Political Economy of Institutional Change. New York. 
Wong, Y. H./Chan, R. Y. (1999): Relationship Marketing in China: Guanxi, Favouritism and Adaptation. In: Journal of Business Ethics 22(2), 107118.

Wong, Y. H./Leung, Thomas K. (2001): Guanxi: Relationship Marketing in A Chinese Context. New York.

Wu, Xiaobo (2007): Thirty Years of Chinese Business. Beijing: Zhongxin Press.

Yan, Yun-xiang (1995): Everyday Power Relations: Changes in a North China Village. In: Walder, Andrew A./Walder, G. (eds.): The Waning of the Communist State. Berkeley. 215-241.

Yang, Mayfair (2002): The Resilience of Guanxi and Its New Deployments: A Critique of Some New Guanxi Scholarship. In: The China Quarterly (170), 459-476.

Yang, Mayfair M. (1994): Gifts, Favors, and Banquets: The Art of Social Relationships in China. London.

Yeung, Irene Y.M./Tung, Rosalie L. (1996): Achieving Business Success in Confucian Societies. The Importance of Guanxi (Connections). In: Organizational Dynamics 25(2), 54-65. 
